\title{
MINERALOGICAL AND CHEMICAL STUDIES ON SOME MINERALS USED IN PHARMACEUTICAL INDUSTRIES IN EGYPT BY
}

Ahmed Mohamed El-Mezayen, Gehad Mohamed Saleh, Hatem Mohamed Abdou El-Desoky, Bassam Mohamed Said Khalil, Ahmed Mahmoud Samy

FROM

Department of geological Technology, Faculty of science, and Pharmaceutics Department, Faculty of Pharmacy, Al-Azhar University, Nasr City, Cairo, Egypt,

\begin{abstract}
Background: Suitable minerals for use in the pharmaceutical industry can be derived from Egyptian desert. Aim: mineralogical \& chemical studies on some minerals used in pharmaceutical industries in Egypt.

Large numbers of minerals are used in pharmaceutical industries as well as in cosmetic product.

Physiochemical properties of these minerals play an important role in using of these minerals in pharmaceutical industries; hence, these properties were evaluated and compared with commercial brands that stipulated with the enforced pharmacopoeia.

A material to be used in pharmaceutical formulations must have low or zero toxicity \& non carcinogen.

And we were able through tests to prove that minerals under study conformed to international standards for minerals use in medicines and prescribed in British pharmacopeia (2009) \& European Medicines Agency Pre-authorization Evaluation of Medicines for Human Use.
\end{abstract}

\section{Introduction}

The role of industrial minerals in pharmaceuticals falls into one of two main categories: excipients or active substance. The excipients have no intrinsic health benefit on their own; they are used solely as carriers, allowing the intake of minute amounts of active substances, in a practical way.

Minerals in pharmaceutical and cosmetic preparations a large number of minerals are used as active ingredients in pharmaceutical preparations as well as in cosmetic products. Some minerals have been used for therapeutic purposes since prehistoric times. The therapeutic activity of these minerals is controlled by their physical and physico-chemical properties as well as their chemical composition; a material to be used in pharmaceutical formulations must have low or zero toxicity.

Those minerals with a high sorption capacity and a large specific surface area can also function in pharmaceutical preparation as gastrointestinal and dermatological protectors, and anti-inflammatories and local anesthetics, while water-soluble species can be used as homeostatics, antianemics and decongestive eye drops. Likewise, minerals with a high heat retention capacity can serve as anti-inflammatories and local anesthetics, minerals with high astringency are used as antiseptics and disinfectants and minerals which react with cysteine can serve as keratolytic reducers

In other hand Water-soluble species can be utilized in cosmetic product as ingredients in toothpastes and bathroom salts. Those minerals with a high sorption capacity and a large specific surface area can function as creams, powders and emulsions while minerals with proper hardness can act as abrasives in toothpastes. Highly opaque minerals and minerals of high reflectance are used in creams, powders and emulsions. Likewise, minerals with high astringency are included in deodorants. 
Acid neutralization increases the $\mathrm{pH}$ of the gastric fluid from 1.5-2.0 to $\geq 7$, depending on mineral type. According to current opinion, an effective antacid is one that elevates the $\mathrm{pH}$ by 3-4 units, and causes the disappearance of "free acidity". When the $\mathrm{pH}$ of the gastric fluid exceeds 7, "acid rebound" may occur by which the parietal glands are stimulated in order to restore normal acidity.

\section{Materials and Methods \\ Mineralogical analysis}

X-ray Powder Diffraction (XRD) is most widely used for the identification of unknown crystalline materials (e.g. minerals and other inorganic compounds). Determination of unknown solids is critical to study in geology, environmental science, material science, engineering and biology.

Mineral analyses were carried out using the X-ray Powder Diffraction (XRD) technique at the Laboratories of the Central Metallurgical Researching and development Institute (CMRDI) to be used in determination the mineralogical composition of the studied samples, by means of X-ray diffraction (XRD) using a SIEMENSD 5000-type diffractometer with $\mathrm{Cu}$ $\mathrm{K} \alpha$ radiation, a graphite monochromator, $40 \mathrm{k} \mathrm{V}, 30 \mathrm{~mA}$, at 10 counts/s over a $2 \theta$ range from $4^{\circ}$ to $70^{\circ}$.

\section{Chemical analysis}

Uranium analysis in different processing stream was analyzed by an oxidimetric titration method using ammonium metavanadate. A previous uranium reduction was performed by ammonium ferrous sulfate in the presence of diphenylsulfonate as indicator until its color changes to slightly violet red color.

$\mathrm{U}(\mathrm{g} / \mathrm{L})=\mathrm{T} . \mathrm{V}_{1} / \mathrm{V} .1000$ where:-

$\mathrm{T}$ : Titration intensity of $\mathrm{NH}_{4} \mathrm{VO}_{3}$ to $\mathrm{U} \mathrm{g} / \mathrm{ml}$

$\mathrm{V}_{1}$ : Volume taken of $\mathrm{NH}_{4} \mathrm{VO}_{3}$ solution $(\mathrm{ml})$

$\mathrm{V}$ : Volume of sample (ml).

Thorium was chemically determined by the colored method using Arsenazo-III, as an indicator. The colored method was performed using a spectrophotometer technique. The accuracy and precision of both uranium as well as thorium element analysis were estimated using a series of international reference standards. All chemical and mineral analyses were carried out in the Nuclear Materials Authority laboratories, Cairo, Egypt.

2.2- Trace elements were carried out at Nuclear Materials Authority laboratories, Egypt by using X-ray fluorescence (XRF) techniques using Philips X-Unique II spectrometer (PW$1510)$ with automatic sample changer. The analytical error is estimated about $\pm 5 \mathrm{ppm}$. Absolute accuracy has been assessed by comparison with international reference materials analyzed along with the samples and is generally less than $2 \%$.

2.3- Determinations of major oxides were carried out using wet chemical analytical technique with \pm 2 wt. \% error for most oxides. These analyses were carried out at Nuclear Materials Authority laboratories. $\mathrm{SiO}_{2}, \mathrm{Al}_{2} \mathrm{O}_{3}, \mathrm{TiO}_{2}$ and $\mathrm{P}_{2} \mathrm{O}_{5}$ were determined colormetrically using Spectrophotometer. $\mathrm{Na}_{2} \mathrm{O}$ and $\mathrm{K}_{2} \mathrm{O}$ were determined using Flame Photometer. $\mathrm{CaO}, \mathrm{MgO}$ and $\mathrm{Fe}_{2} \mathrm{O}_{3}$ (total iron) were determined by means of complex titermetric technique, while special volumetric technique was used for measuring $\mathrm{FeO}$. $\mathrm{MnO}$ was measured by Atomic Absorption. The loss of ignition was measured gravimetrically.

\section{Solubility Tests}

The inorganic and organic chemical solvent substances required to solubility tests were listed in the following tables (1) and (2). 
Table 1. Inorganic chemicals required for solubility tests and their characters.

\begin{tabular}{|c|c|c|c|c|}
\hline Required chemicals & Chemical formula & Molarity & Normality & Concentrations \\
\hline Dilute hydrochloric acid & $\mathrm{HCL}$ & 0.5 & 0.5 & $5.2 \%$ \\
\hline $\begin{array}{c}\text { Concentrate hydrochloric } \\
\text { acid }\end{array}$ & $\mathrm{HCL}$ & 12 & 12 & $37 \%$ \\
\hline Dilute acetic acid & $\mathrm{CH}_{3} \mathrm{COOH}$ & 1.84 & 1.84 & $11 \%$ \\
\hline Concentrate sulfuric acid & $\mathrm{H}_{2} \mathrm{SO}_{4}$ & 18.4 & 36.8 & $98 \%$ \\
\hline Dilute sulfuric acid & $\mathrm{H}_{2} \mathrm{SO}_{4}$ & 0.5 & 1 & $5 \%$ \\
\hline Nitric acid & $\mathrm{HNO}_{3}$ & 15 & 15 & $68 \%$ \\
\hline
\end{tabular}

Table 2. Organic solvent used for solubility tests and their characters.

\begin{tabular}{|c|c|c|c|c|c|c|c|}
\hline Solvent & $\begin{array}{l}\text { Insulating } \\
\text { constant }\end{array}$ & $\begin{array}{c}\text { Boiling } \\
\text { point }\end{array}$ & $\begin{array}{l}\text { Chemical } \\
\text { formula }\end{array}$ & Density & $\begin{array}{c}\delta \mathrm{H} \\
\text { Hydrogen } \\
\text { bonding }\end{array}$ & $\begin{array}{c}\delta \mathrm{P} \\
\text { Polar }\end{array}$ & $\begin{array}{c}\delta \mathrm{D} \\
\text { Dispersion }\end{array}$ \\
\hline \multicolumn{8}{|c|}{ Non polar solvent } \\
\hline Benzene & 2.3 & $80^{\circ} \mathrm{C}$ & $\mathrm{C}_{6} \mathrm{H}_{6}$ & $\begin{array}{c}0.879 \\
\mathrm{~g} / \mathrm{ml}\end{array}$ & 2 & 0 & 18.4 \\
\hline $\begin{array}{l}\text { diethyl } \\
\text { ether }\end{array}$ & 4.3 & $35^{\circ} \mathrm{C}$ & $\begin{array}{c}\mathrm{CH}_{3} \mathrm{CH}_{2^{-}} \\
\mathrm{O}-\mathrm{CH}_{2-}^{-} \\
\mathrm{CH}_{3}\end{array}$ & $\begin{array}{r}0.713 \\
\mathrm{~g} / \mathrm{ml}\end{array}$ & & & \\
\hline \multicolumn{8}{|c|}{ Polar solvent } \\
\hline Ethanol & 24.55 & $79^{\circ} \mathrm{C}$ & $\begin{array}{c}\mathrm{CH}_{3^{-}} \\
\mathrm{CH}_{2}-\mathrm{OH}\end{array}$ & $\begin{array}{c}0.789 \\
\mathrm{~g} / \mathrm{ml}\end{array}$ & 19.4 & 8.8 & 15.8 \\
\hline Water & 80 & $100^{\circ} \mathrm{C}$ & $\mathrm{H}-\mathrm{O}-\mathrm{H}$ & $\begin{array}{c}1.000 \\
\mathrm{~g} / \mathrm{ml}\end{array}$ & 42.3 & 16 & 15.5 \\
\hline
\end{tabular}

\section{Atomic absorption spectroscopy (AAS)}

Atomic absorption spectroscopy (AAS) is a spectroanalytical procedure for the quantitative determination of chemical elements (hematite, magnetite and ilmenite) using the absorption of optical radiation (light) by free atoms in the gaseous state.

In analytical chemistry the technique is used for determining the concentration of a particular element (the analyte) in a sample to be analyzed. AAS can be used to determine over 70 different elements in solution or directly in solid samples used in pharmacology, biophysics and toxicology research.

The solubility, TDS, $\mathrm{P}^{\mathrm{H}}$ and AAS worked at chemistry laboratory, Faculty of Science, Al-Azhar University.

\section{Microbial Contamination}

Inoculation and incubation

The tools that used in this test are:-

Sterile Petri dishes made of glass or plastic, $90 \mathrm{~mm}$ to $100 \mathrm{~mm}$ in diameter.

Pipette of nominal capacity $1 \mathrm{ml}$.

Incubator capable of operating at $30^{\circ} \mathrm{C} \pm 1{ }^{\circ} \mathrm{C}$.

Counting of colonies

Examine the dishes under subdued light

The medium of the incubation: - Plate count agar (PCA) 
Composition of Plate count agar (PCA)

Enzymatic digestion of casein

Yeast extract

Glucose, anhydrous $\left(\mathrm{C}_{6} \mathrm{H}_{12} \mathrm{O}_{6}\right)$

Agar1

Water

\author{
$5.0 \mathrm{~g}$ \\ $2.5 \mathrm{~g}$ \\ $1.0 \mathrm{~g}$ \\ $9 \mathrm{~g}$ to $18 \mathrm{~g}$ \\ $1000 \mathrm{ml}$
}

By East African Standard (EAS) 68-1 (2006). Methods of microbiological examination, Part 1: Total plate count. This technique carried out at special laboratory.

\section{RESULTS}

Since the minerals, this conducted the study non-carcinogenic or toxic and what we were able through tests to prove that minerals under study conformed to international standards for minerals use in medicines and prescribed in British pharmacopeia (2009).

Even though some of the impurities found in the minerals under study and can be controlled by reducing the dose or the quantity added of the minerals on the drugs as stipulated in European Medicines Agency Pre-authorization Evaluation of Medicines for Human Use Doc. Ref. (2007) CPMP/SWP/QWP/4446/00corr.

After all this evidence it can be stated that the minerals under study can be used in the pharmaceutical industries (drugs \&/or cosmetics)

\section{Discussion}

After crushing and grinding samples, mineralogical analysis has been made of X-ray diffraction on these samples, which are needed to identify the minerals practically through the crystal structure the results were to prove the identity of the minerals.

The results of the X-ray diffraction of these samples are as follows, graphite (graphite with a very little amount of quartz), ilmenite (ilmenite with a small amount of clinochlore), pyrolusite (clean pyrolusite), barite (clean barite), gypsum (clean gypsum), anhydrite (clean anhydrite), magnesite (magnesite with very little amount of dolomite \& halite), dolomite (dolomite very little amount of calcite), limestone (clean calcite), fluorite (fluorite with a very little amount of quartz), talc (talc with a very little amount of montmorillonite \& kaolinite), microcline (microcline with a very little amount of illite $\&$ albite), muscovite (clean muscovite), kaolin (kaolin with a very little amount of montmorillonite \& quartz).

And therefore it has been to move to the chemical analysis and of the major oxide, trace element, and rare earth's metals and are required to prove the purity metals, where were the result of the purity of samples as follows, graphite $(63.7 \%)$, ilmenite $(68.6 \%)$, pyrolusite (65.7\%), barite (64.6\%), gypsum (93\%), anhydrite (93.5\%), magnesite (99.7\%), dolomite $(98.8 \%)$, limestone $(100 \%)$, fluorite $(65.2 \%)$, talc $(71.7 \%)$, microcline $(83 \%)$, muscovite $(92.4 \%)$ and kaolinite $(98.9 \%)$.

Table 3. Uranium and Thorium Analysis for (14) Samples representative Egyptian minerals in pharmaceuticals industry

\begin{tabular}{|c|c|c|c|c|c|c|c|c|c|c|c|c|c|c|}
\hline$\frac{\tilde{\omega}}{\tilde{\Xi}}$ & 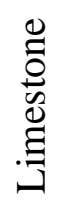 & 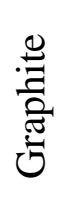 & 节 & 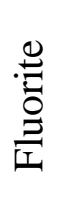 & 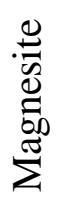 & 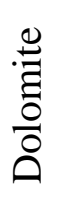 & 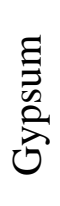 & 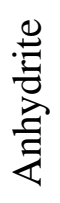 & 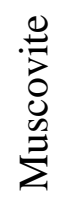 & 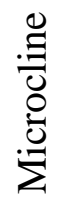 & 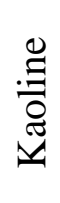 & 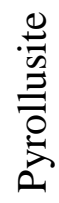 & $\begin{array}{l}\stackrel{0}{\Xi} \\
\stackrel{\Xi}{\Xi} \\
\stackrel{\Xi}{\Xi}\end{array}$ & $\frac{u}{\tilde{H}}$ \\
\hline U ppm & 11 & 6 & 10 & 25 & 4 & 5 & 2 & 4 & 36 & 14 & 11 & 2 & 9 & 9 \\
\hline Th ppm & 18 & 4 & 8 & 14 & 8 & 9 & 3 & 7 & 12 & 20 & 14 & 4 & 11 & 12 \\
\hline
\end{tabular}


Table 4. XRF Analysis for (14) Samples representative Egyptian minerals in pharmaceuticals industry

\begin{tabular}{|c|c|c|c|c|c|c|c|c|c|c|c|c|c|}
\hline $\begin{array}{c}\text { Sample } \\
\text { No. }\end{array}$ & $\mathrm{Cr}$ & $\mathrm{Ni}$ & $\mathrm{Cu}$ & $\mathrm{Zn}$ & $\mathrm{Zr}$ & $\mathrm{Rb}$ & $\mathrm{Y}$ & $\mathrm{Ba}$ & $\mathrm{Pb}$ & $\mathrm{Sr}$ & $\mathrm{Ga}$ & $\mathrm{V}$ & $\mathrm{Nb}$ \\
\hline Limestone & 10 & 6 & 9 & 7 & 33 & 2 & 8 & 16 & u.d & 2 & 3 & u.d & 5 \\
\hline Barite & u.d & 6 & 7 & 4 & 5 & 2 & u.d & $>10000$ & u.d & u.d & u.d & 141 & u.d \\
\hline Fluorite & 5 & 7 & 9 & 42 & 105 & 7 & 23 & 2350 & 52 & 3 & 25 & 16 & 16 \\
\hline Magnesite & 30 & 107 & 13 & 13 & 19 & u.d & 7 & 38 & 7 & u.d & 13 & u.d & 3 \\
\hline Dolomite & 21 & 11 & 8 & 101 & 46 & 4 & 14 & 52 & 17 & 3 & 12 & u.d & 8 \\
\hline Gypsum & 8 & 6 & 8 & 255 & 963 & u.d & 196 & 30 & 6 & 50 & 4 & u.d & 145 \\
\hline Anhydrite & 20 & 6 & 8 & 9 & 233 & u.d & 48 & 14 & u.d & 12 & 4 & u.d & 35 \\
\hline Muscovite & 53 & 7 & 21 & 126 & 8 & 1172 & 11 & 192 & 3 & u.d & 5 & 7 & 2 \\
\hline Microcline & 19 & 7 & 12 & 9 & 85 & 214 & 32 & 331 & 31 & 4 & 23 & 2 & 14 \\
\hline Kaoline & 104 & 36 & 19 & 73 & 787 & 84 & 354 & 2833 & 18 & 29 & 12 & 78 & 137 \\
\hline Talc & 696 & 999 & 11 & 32 & 9 & u.d & 5 & 43 & 9 & u.d & 10 & 5 & u.d \\
\hline Pyrollusite & 25 & 26 & 170 & 354 & 14 & u.d & u.d & 298 & 39 & 26 & 16 & 25 & u.d \\
\hline Graphite & 412 & 138 & 38 & 68 & 87 & 15 & 5 & 3697 & 8 & 136 & 9 & 191 & 4 \\
\hline Ilmenite & 275 & 165 & 217 & 68 & 88 & 2 & 5 & $>10000$ & 4 & 137 & 4 & 1826 & 4 \\
\hline Chromite & $>10000$ & 397 & 15 & 103 & u.d & 2 & u.d & 846 & 24 & u.d & 15 & 303 & u.d \\
\hline
\end{tabular}

\section{The result of solubility of these samples as follows:}

Graphite practically insoluble in all usual solvents, Ilmenite soluble in mineral acids; insoluble in water, Pyrolusite freely soluble in water, practically insoluble in ethanol, Barite practically insoluble in water and in organic solvents. It is very slightly soluble in acids and in solutions of alkali hydroxides, Gypsum very slightly soluble in water, practically insoluble in ethanol, Anhydrite practically insoluble in ethanol, slightly soluble in water more soluble in dilute mineral acids, Magnesite and Dolomite practically insoluble in water It dissolves in dilute acids with effervescence, Limestone practically insoluble in water It is very slightly soluble in acids and in solutions of alkali hydroxides, Fluorite soluble in water, practically insoluble in ethanol, Talc practically insoluble in dilute acids and alkalis hydroxide, organic solvents, ethanol and water, Microcline and Muscovite freely soluble in water, very soluble in boiling water soluble in glycerol practically insoluble in ethanol, Kaolin practically insoluble in water and in organic solvents

Meanings of the terms used in statements of approximate solubilities.

Descriptive term

Very soluble

Freely soluble

Soluble

Sparingly soluble

Slightly soluble

Very slightly soluble

Practically insoluble

The term 'partly soluble' is used to describe a mixture of which only some of the components gram of solute per approximate volume of solvent

in milliliters

Less than 1

From 1 to 10

From 10 to 30

From 30 to 100

From 100 to 1000

From 1000 to 10000

More than 10000 dissolve. 
Table 5. Comparison between solubility of minerals samples and standard reference samples.

\begin{tabular}{|c|c|c|c|c|c|c|c|}
\hline No & Name & $\begin{array}{l}\text { ASDF } \\
\text { Per-DF }\end{array}$ & $\begin{array}{c}\text { Conc } \\
.\end{array}$ & $\begin{array}{l}\text { A: } \mathrm{mg} / \mathrm{l} \\
\mathrm{O}: \mathrm{mg} / \mathrm{l}\end{array}$ & $\mathrm{Cl}$ & $\mathrm{SD}$ & $\mathrm{RSD} / \%$ Rem \\
\hline \multirow{2}{*}{8} & \multirow{2}{*}{ Hematite } & \multirow{2}{*}{1.000} & A: & 12.09 & $\begin{array}{l}3.6 \\
77\end{array}$ & $\begin{array}{c}0.0387 \\
6\end{array}$ & \multirow{2}{*}{$\begin{array}{l}0.321>\mathrm{CAL} \\
0.321>\mathrm{CAL}\end{array}$} \\
\hline & & & O: & 12.09 & $\begin{array}{l}3.6 \\
77 \\
\end{array}$ & $\begin{array}{c}0.0387 \\
6\end{array}$ & \\
\hline \multirow{2}{*}{9} & \multirow{2}{*}{$\begin{array}{c}\text { Magnetit } \\
\text { e }\end{array}$} & \multirow{2}{*}{1.000} & \multirow{2}{*}{$\begin{array}{l}\text { A: } \\
\text { O: }\end{array}$} & 9.957 & $\begin{array}{l}2.8 \\
84\end{array}$ & $\begin{array}{c}0.0258 \\
0\end{array}$ & \multirow{2}{*}{$\begin{array}{l}0.259>\mathrm{CAL} \\
0.259>\mathrm{CAL}\end{array}$} \\
\hline & & & & 9.957 & $\begin{array}{l}2.8 \\
84\end{array}$ & $\begin{array}{c}0.0258 \\
0\end{array}$ & \\
\hline \multirow{2}{*}{10} & \multirow{2}{*}{ Ilmenite } & \multirow{2}{*}{1.000} & \multirow{2}{*}{$\begin{array}{l}\text { A: } \\
\text { O: }\end{array}$} & 12.58 & $\begin{array}{l}3.8 \\
64 \\
\end{array}$ & $\begin{array}{c}0.0262 \\
1\end{array}$ & \multirow{2}{*}{$\begin{array}{l}0.208>\mathrm{CAL} \\
0.208>\mathrm{CAL}\end{array}$} \\
\hline & & & & 12.58 & $\begin{array}{l}3.8 \\
64\end{array}$ & $\begin{array}{c}0.0262 \\
1\end{array}$ & \\
\hline
\end{tabular}

\section{Physicochemical Characterization}

The therapeutic action is often correlated with the physical and physicochemical properties of the mineral; in other instances, it is related to the ionic composition of the mineral. In common with organic active ingredients, minerals in contact with the human body will pass through one or several of the following phases: liberation, absorption, distribution, metabolism and excretion, which together are referred to by the acronym 'LADME. The type and number of phases will depend on the nature of the mineral, the way of administration (oral, topical, Parenteral), and the kind of formulation (tablets, suspensions, powder, etc.).

\section{Microbiological evaluation}

Total viable aerobic count not more than $10^{3}, 10^{2}, 10^{3}$ micro-organisms per gram, for Graphite, Talc, kaolin respectively. Determined by plate-count. Where the practical results are $92,27,83$ by the same succession.

\section{Conclusion}

The minerals that collected from Egyptian desert have some desired pharmacopoeial, physicochemical and microbiological properties required for pharmaceutical applications. These minerals are generally have non-toxic ions, vastly available in many regions in Egypt $\&$ very low cost than that of imported minerals, Egyptian minerals have the same comparable physicochemical properties to that of commercial brand. 


\section{Pharmaceutical characterization}

Table 6. Pharmacopoeial Characterization for minerals that used in pharmaceutical industries.

\begin{tabular}{|c|c|c|c|}
\hline Mineral & Chemical formulae & $\begin{array}{l}\text { Method of } \\
\text { administration }\end{array}$ & Therapeutic activity or cosmetic action \\
\hline \multicolumn{4}{|c|}{ Native elements (non metal) } \\
\hline Graphite & $\mathrm{C}$ & \multirow{2}{*}{$\begin{array}{l}\text { Topically } \\
\text { Orally }\end{array}$} & \multirow{2}{*}{ Adsorbent, antimicrobial preservative } \\
\hline Coal & $\mathrm{C}$ & & \\
\hline \multicolumn{4}{|l|}{ Oxides } \\
\hline Hematite & $\mathrm{Fe}_{2} \mathrm{O}_{3}$ & \multirow{3}{*}{ Topically } & \multirow{3}{*}{$\begin{array}{l}\text { cosmetics and excipients as iron and } \\
\text { multi vitamins }\end{array}$} \\
\hline Magnetite & $\mathrm{Fe}_{3} \mathrm{O}_{4}$ & & \\
\hline Ilmenite & $\mathrm{FeTiO}_{3}$ & & \\
\hline Corundum & $\mathrm{Al}_{2} \mathrm{O}_{3}$ & Parenterally & $\begin{array}{l}\text { Discoloring powders and is particularly } \\
\text { widely used in antibiotic formulations. }\end{array}$ \\
\hline Pyrolusite & $\mathrm{MnO}_{2}$ & Orally & Simple and multivitamins \\
\hline Rutile & $\mathrm{TiO}_{2}$ & Topically & $\begin{array}{l}\text { Dermatological protector, solar } \\
\text { protector }\end{array}$ \\
\hline Phospherite & $\mathrm{P}_{2} \mathrm{O}_{5}$ & $\begin{array}{l}\text { Orally } \\
\text { parenterally }\end{array}$ & Excipient, anti acid \& vaccine adjuvant \\
\hline \multicolumn{4}{|l|}{ Sulfide } \\
\hline Galena & $\mathrm{PbS}$ & Topically & Cosmetic \\
\hline \multicolumn{4}{|l|}{ Sulfates } \\
\hline Barite & $\mathrm{BaSO}_{4}$ & Orally & $\begin{array}{l}\text { Investigation of the gastro-intestinal } \\
\text { tract. }\end{array}$ \\
\hline Gypsum & $\mathrm{CaSO}_{2} \cdot 2 \mathrm{H}_{2} \mathrm{O}$ & & Calcium sulfate dihydrate is used in the \\
\hline Anhydrite & $\mathrm{CaSO}_{4}$ & & formulation of tablets and capsules. \\
\hline Alabaster & $\mathrm{CaSO}_{4}$ & $\begin{array}{l}\text { Topically } \\
\text { parenterally }\end{array}$ & $\begin{array}{l}\text { Calcium sulfate hemihydrates are used } \\
\text { in the preparation of plaster of Paris } \\
\text { bandage; Anhydrous calcium sulfate is } \\
\text { used as adesiccant. . Therapeutically, } \\
\text { calcium sulfate is used in dental and } \\
\text { craniofacial surgical procedures }\end{array}$ \\
\hline \multicolumn{4}{|l|}{ Carbonate } \\
\hline Limestone & $\mathrm{CaCO}_{3}$ & \multirow[b]{2}{*}{ Orally, topically } & \multirow{2}{*}{$\begin{array}{l}\text { Antacid, antidiarrhoeaics, mineral } \\
\text { supplement, abrasive and polishing } \\
\text { agent in toothpaste }\end{array}$} \\
\hline Calcite & $\mathrm{CaCO}_{3}$ & & \\
\hline Magnetite & $\mathrm{MgCO}_{3}$ & \multirow{2}{*}{ Orally } & \multirow{2}{*}{$\begin{array}{l}\text { Antacid, osmotic oral laxative, mineral } \\
\text { supplement }\end{array}$} \\
\hline Dolomite & $\mathrm{CaMg}\left(\mathrm{CO}_{3}\right)_{2}$ & & \\
\hline \multicolumn{4}{|l|}{ Halogen } \\
\hline Halite & $\mathrm{NaCl}$ & $\begin{array}{l}\text { Orally, } \\
\text { parenterally, } \\
\text { topically }\end{array}$ & $\begin{array}{l}\text { Homeostatic, mineral supplement, } \\
\text { decongestive eye drops, bathroom salts }\end{array}$ \\
\hline Fluorite & $\mathrm{CaF}_{2}$ & Topically & Prevention of dental caries. \\
\hline \multicolumn{4}{|l|}{ Silicates } \\
\hline Asbestos & $\mathrm{Mg}_{3} \mathrm{Si}_{2} \mathrm{O}_{5}(\mathrm{OH})_{4}$ & \multirow{2}{*}{ Topically } & \multirow{2}{*}{$\begin{array}{l}\text { Dermatological protector, cosmetic } \\
\text { creams, powders and emulsions }\end{array}$} \\
\hline Talc & $\mathrm{Mg}_{3} \mathrm{Si}_{4} \mathrm{O}_{10}(\mathrm{OH})_{2}$ & & \\
\hline Microcline & $\mathrm{KAlSi}_{2} \mathrm{O}_{8}$ & \multirow{5}{*}{ Topically } & \multirow{5}{*}{$\begin{array}{l}\text { Cosmetic } \\
\text { emulsions }\end{array}$} \\
\hline Orthoclase & $\mathrm{KAlSi}_{3} \mathrm{O}_{8}$ & & \\
\hline Muscovite & $\mathrm{KAl}_{3} \mathrm{Si}_{3} \mathrm{O}_{10}(\mathrm{OH})_{2}$ & & \\
\hline Phlogopite & $\begin{array}{l}\mathrm{K}(\mathrm{Mg}, \mathrm{Fe})_{3} \mathrm{AlSi}_{3} \mathrm{O}_{10}(\mathrm{OH} \\
\end{array}$ & & \\
\hline Quartz & $\mathrm{SiO}_{2}$ & & \\
\hline Kaolin & $\mathrm{Al}_{2} \mathrm{Si}_{2} \mathrm{O}_{5}(\mathrm{OH})_{4}$ & Orally, topically & $\begin{array}{l}\text { Gastrointestinal } \text { protector, } \\
\text { antidiarrhoeaics, dermatological } \\
\text { protector, anti-inflammatory and local } \\
\text { anesthetic, cosmetic creams, powders } \\
\text { and emulsions }\end{array}$ \\
\hline
\end{tabular}




\section{REFERENCES}

Bech, J., 1987. Les Terres Medicinals. Discurs per Reial Academia de Farmàcia de Barcelona. Reial Acadèmia de farmàcia de Barcelona-CIRIT (Generalitat de Catalunya), Barcelona. 105 pp.

British Pharmacopoeia, 2009. Crown Copyright 2008. Published by The Stationery Office on behalf of the Medicines and Healthcare products.

Brunton, L.L., Lazo, J.S., Parker, K.L., 2005. Goodman \& Gilman's the Pharmacological Basis of Therapeutics, 11e. Ed. McGraw-Hill.

Carretero, M.I., 2002. Clay minerals and their beneficial effects upon human health. A review. Applied Clay Science. Volume 21, Issues 3-4, June 2002, Pages 155-163.

Carretero, M.I., Gomes, C., Tateo, F., 2006. Clays and human health. In: Bergaya, F., Theng, B.K.G., Lagaly, G. (Eds.), Handbook of Clay Science. Elsevier, Amsterdam, pp. 717-741.

Carretero, M.I., Pozo, M., 2009. Clay and non-clay minerals in the pharmaceutical and cosmetic industries Part II. Active ingredients, Applied Clay Science doi:10.1016/j.clay.2009.10.016.

Celso de Sousa Figueiredo Gomes, João Baptista Pereira Silva., 2007. Minerals and clay minerals in medical geology Applied Clay Science 36 (2007) 4-21.

Doc. Ref. London., January, 2007. European Medicines Agency Pre-authorisation Evaluation of Medicines for Human Use CPMP/SWP/QWP/4446/00 corr.

Droy-Lefaix, M.T., Tateo, F., 2006. Clays and clay minerals as drugs. In: Bergaya, F., Theng, B.K.G., Lagaly, G. (Eds.), Handbook of Clay Science. Elsevier, Amsterdam, pp. 743-752.

Egyptian standard, ES: 2732-4/2005. Determination of Chlorine part 4 method of determination of Chlorine content.

Egyptian standard, ES: 2732-5/2005. Determination of Sulphate Part 5, ISO 2480/ 1972. Method of determination of Sulphate content.

Forteza, M., Cornejo, J., Galan, E., 1988. Effects of fibrous clay minerals on dexamethasone stability. Proc. ${ }^{10}$ th Conf. Clay Mineralogy Petrology, 281-286.

Galán, E., Liso, M.J., Forteza, M., 1985. Minerals utilizados en la industria farmaceútica. Boletín de la Sociedad Española de Mineralogía 8, 369-378.

Gomes, C.S.F., Pereira Silva, J.B., 2006. Minerals and Human Health. Benefits and Risks. Centro de Investigação«Minerais Industriais e Argilas». Fudação para a Ciência e a Tecnologia do Ministério da Ciência, Tecnologia e Ensino Superior. Aveiro (Portugal).

Henein Wely Henein., Osama tharwat Latif., 2012. Master on therapeutic drugs. Cover design: Eg. Diaa Gamil, Tel.: 01221012187. Printing: By Number printing house. Deposite NO.: 2008/5892. ISBN: 977-17-5538-2.

Hermosín, M.C., Cornejo, J., White, J.L., Hem, S.L., 1981. Sepiolite. A potential excipient for drugs subject to oxidative degradation. J. Pharm. Sci. 70, 189-192.

Hewitt, J.P., 1992. Titanium dioxide: a different kind of sunshield. Drug and Cosmetic Industry 151 (3), 26-32.

Jaroenworaluck, A., Sunsaneeyametha, W., Kosachan, N., Stevens, R., 2006. Characteristics of silica-coated $\mathrm{TiO} 2$ and its UV absorption for sunscreen cosmetic applications. Surface and Interface Analysis 38, 473-477.

Lefort, D., Deloncle, R., Dubois, P., 2007. Les minéraux en pharmacie. Géosciences 5, 619. 
López-Galindo, A., Viseras, C., Cerezo, P., 2007. Compositional, technical and safety specifications of clays to be used as pharmaceutical and cosmetic products. Applied Clay Science 36 (2007) 51-63.

Merczenko, Z., 1986. Separation and Spectrophotometric Determination of Elements. Harwood, New York, p. 708.

Marczenko, Z., 1986. Spectrophotometric determination of elements, $3^{\text {rd }}$ edition, Ellis Harwood Chichester, U.K, PP.68 -70, 203.

Mondo Minerals, 2014. Talc Applications. Talc for Pharmaceuticals

Note for guidance on impurities, Residual Solvents, 1995. CPMP/ICH/283/ ICHQ3C.

Oscarson, D.W., van Scoyoc, G.E., Ahlrichs, J.L., 1986. Lysis of erythrocytes by silicate minerals. Clays Clay Miner., 34, 74-86.

Pennington, L., 1996. Food sources and dietary intakes of vitamin K1 (phylloquinone) in the American diet: data from the FDA Total Diet Study. J. Am. Diet. Assoc. 96:149154.

Pla Delfina, J.M., Del Pozo Ojeda, A., 1974. Manual de Iniciación a la Biofarmacia. Romargraf, S.A., Barcelona. 315 pp.

Pott, F., Bellmann, B., Mühle, H., Rodelsperger, K., Rippe, R.M., Roller, M., Rosenbruch, M., 1990. Intraperitoneal injection studies for the evaluation of the carcinogenicity of fibrous phyllosilicates. Pp. 319-331 in: Health Related Effects of Phyllosilicates. (J. Bignon, editor) NATO ASI Series G. Ecological Sci. Vol. G21, Springer-Verlag, Heidelberg.

Handbook of Pharmaceutical Excipients., 2009. Published by the Pharmaceutical Press, An imprint of RPS Publishing 1 Lambeth High Street, London SE1 7JN, UK 100 South Atkinson Road, Suite 200, Grayslake, IL 60030-7820, USA and the American Pharmacists Association 2215 Constitution Avenue, NW, Washington, DC 20037-2985, USA.

Rumble, D., 1976. Thermodynamic analysis of phase equilibria in the system $\mathrm{Fe}_{2} \mathrm{TiO}_{4}$ $\mathrm{Fe}_{3} \mathrm{O}_{4}-\mathrm{TiO}_{2}$. Carnegie Inst. Washington Yearb 69: 198-207.

Santarén, J., Alvarez, A., 1994. Assessment of the health effects of mineral dusts. The sepiolite case. Ind. Miner. 319, 101-114.

Shapiro, L., Brannock, W.W., 1962. Rapid analysis of silicate, carbonate, and phosphate rocks. U.S. Geological Survey Bulletin 11214A.

Shapiro, L., Brannock, W.W., 1962. Rapid analysis of silicate, carbonate and phosphate rocks, U. S. Geol. Surv. Bull, 1144-A, 56p.

Department of Health and Human services, U.S., 1991. Analytical \& reporting guidelines: the third national health \& nutrition examination survey, NHANES III, in: NHANES III.

USP32-NF27, This product, is current from May 1, 2009 through April 30, 2010.

Veniale, F., 1997. Applicazioni e utilizzazioni medico-sanitarie di materiali argillosi (naturali e modificati). In: Morandi, N., Dondi, M. (Eds.), Argille e Minerali delle Argille. Guida alla Definizione di Caratteristiche e Proprietà per gli Usi Industriali. Corso di Formazione, Gruppo Ital. AIPEA, Rimini, Italy, pp. 205-239.

Viseras, C., Aguzzi, C., Cerezo, P., Lopez-Galindo, A., 2007. Uses of clay minerals in semisolid health care and therapeutic products. Applied Clay Science. Volume 36, Issues 1-3, April 2007, Pages 37-50. Clays and Health - Clays in Pharmacy, Cosmetics, Pelotherapy, and Environment Protection.

Viseras, C., Lopez-Galindo, A., 1999. Pharmaceutical applications of some Spanish clays (sepiolite, palygorskite, bentonite): some preformulation studies. http://www.sciencedirect.com/science/article/pii/S0169131798000507 
AFF2\#AFF2Applied Clay Science. Volume 14, Issues 1-3, February 1999, Pages 69-82.

Wagner, J.C., Griffiths, D.M., Munday, D.E., 1987. Experimental studies with palygorskite dust. Brit. J. Indus. Med. 44, 749-763.

Ysart, G., Miller, P., Crews, H., 1999. Dietary exposure estimates of 30 elements from the UK total diet study food Addit Contam 16:391-403.

Ysart, G., Miller, P., Crews, H., 2000. Dietary exposure estimates of 30 elements from the UK total diet study food Addit Contam 17:362-411.

Zaghloul, Z.M., Yanni, N.N., Samuel, M.D., Guirgues, N.R., 1982. Characteristics and industrial potentialities of kaolin deposit near Abu Darag, Gulf of Seuz. Desert Inst. Bull., A.R.E., 32, No. 1-2, pp. 19-45.

$$
\text { الملخص العربى }
$$

دراسات معدنية وكيميائية على بعض معادن الصيدلة فى مصر

\section{للسادة الاكاترة}

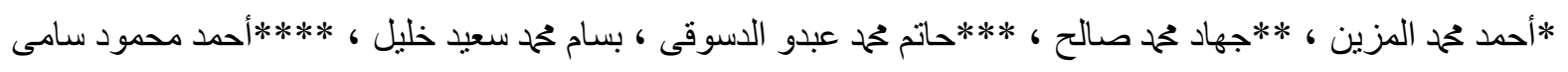
مـنـ

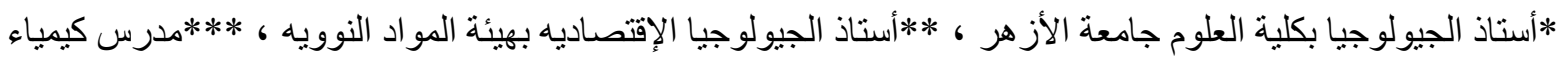

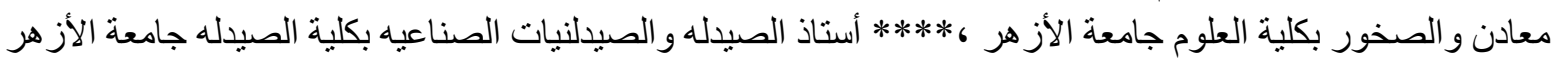

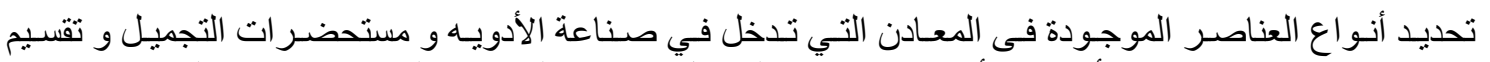

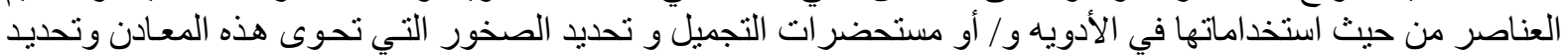

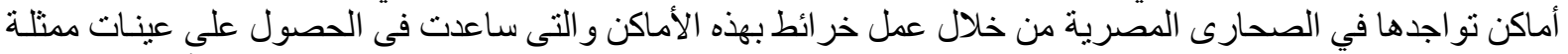

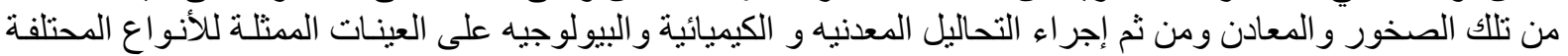

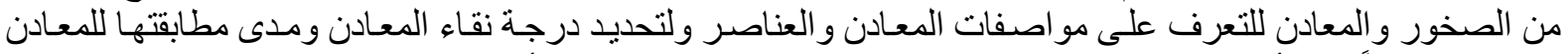

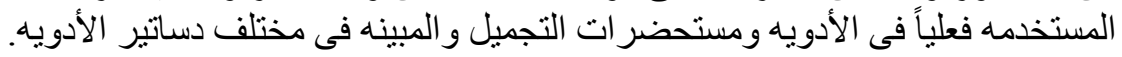

بعد استكمال در اسة هذه النقاط يمكننا الآن أن نقر حقيقه و احده و هى أنه يمكن استخدام المعادن التى انصبت عليت التيها

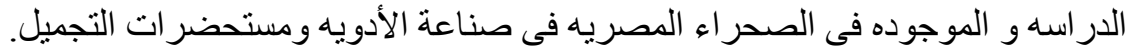

